\title{
RELATIONSHIP KNOWLEDGE AND MOTHER ATTITUDES WITH IMPLEMENTATION OF BABY MASSAGE IN POSKESDES SRI MENANTI DISTRICT LAMPUNG WEST IN 2017
}

\author{
Ani Kristianingsih' Siti Baniyah² \\ ${ }^{1}$ STIKes Aisyah Pringsewu, anikritianingsih@gmail.com \\ 2Mahasiswa DIV Kebidanan, Sitiibaniyah@gmail.com
}

\section{INFO ARTIKEL}

\section{Riwayat Artikel:}

Diterima: 11-01-2018

Disetujui: 30-01-2018

\section{Kata Kunci:}

Pijat Bayi,

Pengetahuan,

Sikap

\section{ABSTRAK}

Abstrak: Di Indonesia Begitu banyak manfaat pijat bayi yang disebutkan di atas perlu diketahui dan dilaksanakan oleh orang tua yang memiliki bayi, karena orang tua kemungkinan memiliki masalah dalam membesarkan anak-anak seperti tidak dapat tidur nyenyak dan kesulitan makan, sehingga rentan terhadap penyakit. Orang tua yang melakukan pemijatan sendiri terhadap bayinya akan belajar memperhatikan bagaimana reaksi bayi pada saat disentuh, mengetahui apa yang disukai dan tidak disukai bayi, sehingga membuat para orang tua lebih mudah mengerti dan menjadi sabar dalam menghadapi masalah yang timbul pada bayinya. Saat orang tua memperhatikan dan mengenali reaksi anak-anaknya dan memberikan responya, bayi memberikan reaksi kembali dan terbangunlah sebuah hubungan yang positif diantara orang tua dan bayi (Health dan Brainbridge, 2007). Tujuan penelitian ini Hubungan Pengetahuan Dan Sikap Ibu Dengan Pelaksanaan Pijat Bayi Di Poskesdes Sri Menanti Kabupaten Lampung Barat Tahun 2017. Jenis Penelitian ini adalah kuantitatif dengan desain penelitian ini menggunakan cross sectional. Sampel dalam penelitian ini adalah 84 orang. Hasil penelitian didapatkan distribusi frekuensi pengetahuan baik 48 (57,1\%) orang. Distribusi frekuensi sikap negatif 46 (54,8\%) orang. Distribusi frekuensi ibu yang melakukan pijat bayi 43 (51,2\%) orang. Ada hubungan pengetahuan dengan pelaksanaan pijat bayi dengan nilai $p$ 0,000.Ada hubungan sikap dengan pelaksanaan pijat bayi dengan nilai $\mathrm{p} 0,000$. Berdasarkan hasil penelitian disarankan kepada ibu untuk melakukan pijat bayi, karena pijat bayi memiliki manfaat baik bagi kesehatan dan tubuh bayi.

\begin{abstract}
In indonesian so many benefits of baby massage mentioned above need to be knows and implemented by parents who have babies, because parents may have problems in raising children such as unable to sleep soundly and difficulty eating, so susceptible to disease. Parents who do their own massage to their babies will learn to pay attention to how the baby reacts at the touch, knowing what the baby likes and dislikes, making it easier for parents to understand and be patient with the problems that arise with their babies (Health and Brainbridge, 2007). The purpose of this study Relationship Knowladge and Mother's Attitude With Implementation Massage Baby At Poskesdes Sri Menanti West Lampung Year 2017. Type this research is quantitative with the design of this study using cross sectional. The sample in this research is 84 people. The result of the research shown that the frequency distribution of knowledge is $48(57,1 \%)$ people. Distribution frequency negative attitude 46 $(54,8 \%)$ people. The frequency distribution of mothers who performed infant massage 43 $(51,2 \%)$ people. There is a relationship of knowledge with the implementation of baby massage with a value of $p 0,000$. There is a relationship attitude with the implementation of baby massage with a value of $p 0,027$. Based on the results of research suggested to the mother to do baby massage, bacause baby massage has benefits both for the health and the baby's body.
\end{abstract}




\section{A. LATAR BELAKANG}

Peraturan Menteri Kesehatan Republik Indonesia Nomor 369/MENKES/SK/III/2007 Tentang Standar Profesi Bidan menyebutkan bahwa bidan mempunyai kewenangan untuk melaksanakan pemantauan dan menstimulasi tumbuh kembang bayi dan anak.Salah satu bentuk stimulasi tumbuh kembang yang selama ini dilakukan oleh masyarakat adalah dengan melakukan pijat bayi.

Pijat bayi merupakan terapi sentuh tertua yang dikenal manusia yang paling popular. Memijat adalah salah satu alternatife yang sudah dibuktikan manfaatnya, tidak hanya orang dewasa bayi juga butuh dipijat meskipun aktivitas yang dilakukan lebih banyak orang dewasa, tetapi proses memijat ini hanya dapat dilakukan pada bayi yang sudah berusia 6 bulan lebih dan bayi tidak dalam keadaan diare dan kenyang (Mahayu, 2016). Pijat adalah seni perawatan kesehatan dan pengobatan yang dipraktikan sejak berabad-abad silam.Laporan tertua tentang seni pijat untuk pengobatan tercatat di Papyrus Ebers, catatan kedokteran zaman Mesir zuno (Maharani, 2009).

Sentuhan pijat bayi setelah kelahiran dapat memberikan jaminan adanya kontak tubuh berkelanjutan yang dapat mempertahankan perasaan aman pada bayi.Laporan tertua tentang seni pijat untuk pengobatan tercatat di Papyrus Ebers yaitu catatan kedokteran zaman mesir kuno, Ayur- Veda buku kedokteran tertua di indiasekitar 1800 SM yang menuliskan tentang pijat, diet dan olahraga sebagai salah satu penyembuhan utama.Sekitar 5000 tahun yang lalu para dokter di Cina dari Dinasti Tang juga meyakini bahwa pijat adalah salah satu dari 4 teknik pengobatan penting (Roesli, 2008).

Pijat bayi mempunyai banyak keuntungan bagi bayi maupun orang tua.Keuntungan berupa fisik, fisiologis dan psikologi. Bagi bayi sendiri dapat memberikan efek fisik yang positif antara lain kenaikan berat badan meningkatkan pertumbuhan dan meningkatkan produksi ASI. Hal ini sudah dibuktikan oleh penelitian Field dan Scafidi (1986 dan 1990) menunjukan bahwa pada 20 bayi prematur yang dipijat 3 kali 15 menit selama 10 hari mengalami kenaikan berat badan per hari $20 \%$ sampai $47 \%$ lebih banyak dari yang tidak dipijat. Penelitian pada bayi cukup bulan yang berusia 1 sampai 3 bulan yang dipijat selama 15 menit sebanyak 2 kali seminggu selama 6 minggu didapatkan kenaikan berat badan yang lebih dari kontrol (Roesli, 2008).

Di Indonesia Begitu banyak manfaat pijat bayi yang disebutkan di atas perlu diketahui dan dilaksanakan oleh orang tua yang memiliki bayi, karena orang tua kemungkinan memiliki masalah dalam membesarkan anak-anak seperti tidak dapat tidur nyenyak dan kesulitan makan, sehingga rentan terhadap penyakit. Orang tua yang melakukan pemijatan sendiri terhadap bayinya akan belajar memperhatikan bagaimana reaksi bayi pada saat disentuh, mengetahui apa yang disukai dan tidak disukai bayi, sehingga membuat para orang tua lebih mudah mengerti dan menjadi sabar dalam menghadapi masalah yang timbul pada bayinya. Saat orang tua memperhatikan dan mengenali reaksi anakanaknya dan memberikan responya, bayi memberikan reaksi kembali dan terbangunlah sebuah hubungan yang positif diantara orang tua dan bayi (Health dan Brainbridge,2007).
Hasil studi pendahuluan yang dilakukan oleh peneliti pada tanggal 8-9 November 2016 terhadap 10 ibu yang mempunyai bayi umur 0-12 bulan pada bulan Januari-Desember 2015 di poskesdes sri menanti, kecamatan air hitam, kabupaten lampung barat bahwa dari 10 ibu yang mempunyai bayi 8 orang belum mengetahui manfaat lebih jauh dari pijat bayi dan belum memahami bagaimana memijat bayi yang benar sehingga banyak ibu yang tidak melaksanakan pijat bayi, Alasan orang tua memijat bayinya karena bayi sedang sakit panas, batuk pilek, rewel dan terjatuh. Maka dari latar belakang tersebut penulis ingin meneliti tentang hubungan pengetahuan dan sikap ibu dengan pelaksanaan pijat bayi di Poskesdes Sri menanti Lampung Barat.

\section{B. METODE PENELITIAN}

Jenis penelitian yang digunakan adalah penelitian kuantitatif yaitu metode penelitian yang berlandaskan pada filsafat positivisme, digunakan untuk meneliti pada populasi atau sampel tertentu (Sugiyono, 2009).

Penelitian ini untuk mengetahui adanya hubungan pengetahuan dan sikap ibu dengan pelaksanaan pijat bayi di poskesdes sri menanti lampung barat tahun 2017.

Penelitian ini dilaksanakan setelah proposal disetujui pada bulan Maret 2017.

Rancangan penelitian ini menggunakan pendekatan Cross sectional yaitu suatu penelitian tiap subyek penelitiannya hanya diobservasi sekali saja dan pengukuran variabel subjek pada saat pemeriksaan. Semua subyek penelitian diamati pada waktu yang sama tanpa memberikan tindak lanjut (Sugiyono, 2009).

Populasi dalam penelitian ini adalah seluruh ibu yang mempunyai bayi yang datang ke poskesdes. Melihat dari data register keseluruhan bayi adalah 84 orang pada bulan Januari 2015.

\section{HASIL DAN PEMBAHASAN}

TABEL 1

Distribusi frekuensi Pelaksanaan pijat bayi di Poskesdes Sri Menanti, Lampung Barat Tahun 2017

\begin{tabular}{llll}
\hline No & Pelaksanaan & Jumlah & Presentase \\
\hline 1 & Tidak & 41 & $48,8 \%$ \\
2 & Ya & 43 & $51,2 \%$ \\
& Jumlah & 84 & $\mathbf{1 0 0 \%}$ \\
\hline
\end{tabular}

Berdasarkan Tabel 1 dari 84 orang, diketahui sebagian besar responden ya pijat bayi sebanyak 43 $(51,2 \%)$ orang, sedangkan yang tidak pijat bayi sebanyak $41(48,8 \%)$.

TABEL 2

Distribusi frekuensi Pengetahuan di Poskesdes Sri Menanti, Lampung Barat Tahun 2017

\begin{tabular}{llll}
\hline No & Pengetahuan & Jumlah & Presentase \\
\hline 1 & Kurang baik & 36 & $42,9 \%$ \\
2 & Baik & 48 & $57,1 \%$ \\
& Jumlah & 84 & $100 \%$ \\
\hline
\end{tabular}

Berdasarkan Tabel 2 dari 84 orang, diketahui sebagian besar responden dengan pengetahuan baik yaitu sebanyak $48(57,1 \%)$ sedangkan pengetahuan kurang baik sebanyak $36(42,9 \%)$ orang. 
TABEL 3

Distribusi frekuensi Sikap di Poskesdes Sri Menanti, Lampung Barat Tahun 2017

\begin{tabular}{llll}
\hline No & Sikap & Jumlah & Presentase \\
\hline 1 & Negatif & 46 & $54,8 \%$ \\
2 & Positif & 38 & $45,2 \%$ \\
& Jumlah & 84 & $100 \%$ \\
\hline
\end{tabular}

Berdasarkan Tabel 3 dari 84 orang, diketahui sebagian besar responden dengan sikap negatif yaitu sebanyak $46(54,8 \%)$ orang sedangkan sikap positif sebanyak $38(45,2 \%)$.

TABEL 4

Hubungan Pengetahuan dengan Pelaksanaan pijat bayi di Poskesdes Sri Menanti, Lampung Barat tahun 2017

\begin{tabular}{|c|c|c|c|c|c|c|c|c|}
\hline \multirow{3}{*}{$\begin{array}{c}\text { Penge } \\
\text { tahua } \\
\text { n }\end{array}$} & \multicolumn{4}{|c|}{$\begin{array}{c}\text { Pelaksanaan Pijat } \\
\text { Bayi }\end{array}$} & \multicolumn{2}{|c|}{ Total } & \multirow{2}{*}{$\begin{array}{c}\mathbf{P} \\
\text { Val } \\
\text { ue } \\
\end{array}$} & \multirow[t]{2}{*}{ OR } \\
\hline & \multicolumn{2}{|c|}{ Tidak } & \multicolumn{2}{|c|}{ Ya } & & & & \\
\hline & $\mathbf{n}$ & $\%$ & $\mathbf{n}$ & $\%$ & $\mathbf{n}$ & $\%$ & & \\
\hline $\begin{array}{c}\text { Kurang } \\
\text { Baik }\end{array}$ & 27 & 75,0 & 9 & 25, & 36 & 100 & 0,00 & 7,3 \\
\hline Baik & 14 & 29,2 & 34 & 70,8 & 48 & 100 & & \\
\hline Jumlah & 41 & 48,8 & 43 & 51,2 & 84 & 100 & & \\
\hline
\end{tabular}

Berdasarkan tabel 4 diketahui dari 36 orang, didapatkan distribusi frekuensi responden yang dengan pengetahuan kurang baik dan tidak pijat bayi sebesar 27 orang (75\%), dan dari 48 orang dengan pengetahuan baik yang tidak pijat bayi sebesar 14 orang (29,2\%). Hasil uji statistik yang dilakukan dengan menggunakan spss diperoleh $p$-value $=0,000<\alpha=0,05$. Hal ini menyatakan bahwa Ha diterima, yang artinya terdapat hubungan pengetahuan dengan pelaksanaan pijat bayi, nilai odds ratio 7,286 artinya responden dengan pengetahuan kurang baik akan memiliki peluang untuk tidak melakukan pijat bayi sebesar 7,2 kali dibandingkan dengan pengetahuan baik.

TABEL 5

Hubungan Sikapdengan Pelaksanaan pijat bayi di Poskesdes Sri Menanti, Lampung Barat tahun 2017

\begin{tabular}{|c|c|c|c|c|c|c|c|c|}
\hline \multirow{3}{*}{ Sikap } & \multicolumn{4}{|c|}{ Pelaksanaan Pijat Bayi } & \multicolumn{2}{|c|}{ Total } & \multirow{3}{*}{$\begin{array}{c} \\
\text { Val } \\
\text { ue }\end{array}$} & \multirow{3}{*}{ OR } \\
\hline & \multicolumn{2}{|c|}{ Tidak } & \multicolumn{2}{|c|}{ Ya } & & & & \\
\hline & $\mathbf{N}$ & $\%$ & $\mathbf{N}$ & $\%$ & $\mathbf{n}$ & $\%$ & & \\
\hline Negatif & 28 & 60,8 & 18 & 39,1 & 46 & 100 & & \\
\hline Positif & 13 & 34,2 & 25 & 65,8 & 38 & 100 & $\begin{array}{l}0,02 \\
7\end{array}$ & 2,991 \\
\hline Jumlah & 41 & 48,8 & 43 & $51,2 \%$ & 84 & 100 & & \\
\hline
\end{tabular}

Berdasarkan tabel 5 diketahui dari 46 orang, didapatkan distribusi frekuensi responden yang dengan sikap negatif dan tidak pijat bayi sebesar 28 orang $(60,8 \%)$, dan dari 38 orang dengan sikap positif yang tidak pijat bayi sebesar 13 orang (34,2\%). Hasil uji statistik yang dilakukan dengan menggunakan spss diperoleh $p$-value $=0,027<\alpha=0,05$. Hal ini menyatakan bahwa Ha diterima, yang artinya terdapat hubungan sikap dengan pelaksanaan pijat bayi, nilai odds ratio 2,991 artinya responden dengan sikap negatif akan memiliki peluang untuk tidak pijat bayi sebesar 2,9 kali dibandingkan dengan sikap negatif.

Berdasarkan hasil penelitian table 1 diatas dapat diketahui bahwa dari 84 orang, terdapat $43(51,2 \%)$ orang ya pijat bayi lebih besar dibandingkan dengan yang tidak pijat bayi. Pijat bayi sebagai bentuk pengobatan alternative menjadi semakin popular karena kesederhanaan, efektifitas biaya, mudah dipelajari dan dapat dilakukan dirumah oleh keluarga, Pijat bayi juga dapat meningkatkan ikatan kasih sayang antara anak dengan orang tua, karena itu pijat bayi sebaiknya dilakukan oleh orang tua bayi (Riksani, 2012).

Penelitian ini sejalan dengan penelitian Mulyati (2013), penelitian berjudul "Hubungan Pengetahuan dan Sikap terhadap Perilaku Ibu dalam Pemijatan Bayi di Puskesmas Pamulang Tahun 2011" dalam penelitian ini penulis menggunakan jenis penelitian kuantitatif desain Cross Sectional. Tekhnik pengambilan sampel menggunakan Simple Random Sampling.Analisis data yang digunakan adalah uji validitas dan realibitas (Pearson Product Moment). Ibu yang melakukan pijat bayi sebanyak 41 orang $(58,6 \%)$.

Berdasarkan hasil penelitian dapat diasumsikan bahwa pijat bayi memiliki manfaat yang baik bagi kesehatan bayi, sehingga pijat bayi penting dan harus dilakukan oleh ibu yang memiliki bayi untuk menjaga kesehatan bayi, memberikan kenyamanan, meningkatkan kasih sayang, dan memberikan kehangatan pada bayi. Ibu yang memberikan pijat bayi pada bayinya akan mempengaruhi kesehatan bayi lebih sehat dan lebih dekat terhadap orang tuanya, karena dapat menumbuhkan rasa kasih sayang bayi terhadap orang tua.

Berdasarkan hasil penelitian pada tabel 2 dari 84 orang, terdapat $48(57,1 \%)$ orang dengan pengetahuan baik lebih besar dibandingkan dengan pengetahuan kurang baik.

Pengetahuan pijat bayi adalah hasil tahu dan kesan dalam perawatan kesehatan dan pengobatan dengan menggunakan permainan gerakan pada bayi untuk merangsang pertumbuhan dan perkembangan serta kemampuan pergerakan bayi secara optimal. Pengetahuan yang perlu ibu ketahui mencakup pengertian pijat bayi, kapan waktunya melakukan pijat bayi, siapa saja yang boleh melakukan pijat bayi, apa yang perlu disiapkan ketika akan memijat bayi dan bagaimana teknik pelaksanaan pijat bayi (Roesli, 2008).

Penelitian ini sejalan dengan penelitian yang dilakukan oleh Nunik dwijayanti nugraheni (2013), penelitian berjudul "Hubungan Tingkat Pengetahuan Dan Akses Informasi Tentang Pijat Bayi Dengan Prilaku Pijat Bayi Oleh Ibu Didesa Purwojati Kecamatan Purwojati Kabupaten Banyumas" dalam penelitian ini penulis menggunakan jenis penelitian metode analitik yang bersifat observasional.Dengan menggunakan desain Crossectional.Teknik pengambilan sampling mengunakan purpose sampling melalui pengumpulan data kuesioner.Analisis data yang dugunakan data adalah univariat dan bivariat (Chi Square). Hasil penelitian ini menunjukkan pengetahuan responden yang baik tentang pijat baik sebanyak 31 orang (91,2\%).

Berdasarkan hasil penelitian dapat diasumsikan bahwa pengetahuan merupakan faktor yang mempengaruhi intelektual individu, dimana semakin tinggi atau semakin baik pengetahuan maka akan semakin memahami manfaat pijat bayi, karena pengetahuan merupakan salah satu determinan yang berpengaruh pada pemahaman orang terhadap objek tertentu, responden dengan tingkat pengetahuan baik akan lebih cepat memahami sesuatu, khususnya pijat bayi terkait dengan manfaat pijat bayi, namun terdapat responden yang tidak memahami manfaat pijat bayi, karena pengetahuan kurang yang disebabkan latar 
belakang responden yang mayoraitas lulusan SMP dan SMA, dengan demikian disarankan kepada ibu untuk meningkatkan pengetahuan tentang pijat bayi dan manfaat pijat bayi dengan cara membaca buku, menonton televise, radio, Koran, majalah, dan bertanya kepada kader ataupun tenaga kesehatan tentang pijat bayi

Berdasarkan hasil penelitian pada tabel 3 dari 84 orang, diketahui sebagian besar responden dengan sikap negatif yaitu sebanyak $46(54,8 \%)$ orang sedangkan sikap positif sebanyak $38(45,2 \%)$.

Sikap ibu terhadap pelaksanaan pijat bayi adalah sikap yang terbentuk dari interaksi sosial dipengaruhi oleh pengalaman pribadi, kebudayaan, orang yang dianggap penting, media massa, lembaga pendidikan atau agama, emosi seseorang. Kemudian manusia bersikap menerima atau menolak yang terjadi (Azwar, 2011). Dalam hal ini pemberian sentuhan dalam pemijatan bayi pandangan mata antara orang tua dengan bayi mampu mengalirkan sikap jalinan kasih yang merupakan jalinan komunikasi untuk memupuk cinta kasih secara timbal balik diantara keduanya.Mampu mengurangi kecemasan, meningkatan kemampuan fisik serta meningkatkan percaya diri (Roesli, 2009).

Penelitian ini sejalan dengan penelitian Mulyati (2013), penelitian berjudul "Hubungan Pengetahuan dan Sikap terhadap Perilaku Ibu dalam Pemijatan Bayi di Puskesmas Pamulang Tahun 2011" dalam penelitian ini penulis menggunakan jenis penelitian kuantitatif desain Cross Sectional. Tekhnik pengambilan sampel menggunakan Simple Random Sampling.Analisis data yang digunakan adalah uji validitas dan realibitas (Pearson Product Moment).Sikap positif ibu sebanyak 35 orang (50\%) dan negatif 35 orang (50\%).

Berdasarkan hasil penelitian dapat diasumsikan bahwa sikap merupakan determinan yang mempengaruhi individu untuk melakukan pijat bayi, dimana semakin positif sikap ibu maka akan semakin besar melakukan pijat bayi, sikap ibu yang positif dapat dipengaruhi oleh tenaga kesehatan yang memberikan pendidikan kesehatan tentang pijat bayi, sehingga ibu terbiasa melakukan pijat bayi pada anaknya sesuai dengan kebutuhan bayi, dan bayi pun dapat menikmati manfaat yang diberikan, dengan demikian disarankan kepada ibu untuk melakukan pijat bayi, karena pijat bayi memiliki manfaat baik bagi kesehatan dan tubuh bayi, dan disarankan kepada ibu yang memiliki bayi untuk bertanya pada tenaga kesehatan agar mendapatkan konseling pijat bayi, sehingga ibu melakukan pijat bayi dengan benar dan teratur.

Berdasarkan tabel 4diketahui dari 36 orang, didapatkan distribusi frekuensi responden yang dengan pengetahuan kurang baik dan tidak pijat bayi sebesar 27 orang $(75 \%)$, dan dari 48 orang dengan pengetahuan baik yang tidak pijat bayi sebesar 14 orang $(29,2 \%)$. Hasil uji statistik yang dilakukan dengan menggunakan spss diperoleh p-value $=0,000<\alpha=0,05$. Hal ini menyatakan bahwa Ha diterima, yang artinya terdapat hubungan pengetahuan dengan pelaksanaan pijat bayi, nilai odds ratio 7,286 artinya responden dengan pengetahuan kurang baik akan memiliki peluang untuk tidak melakukan pijat bayi sebesar 7,2 kali dibandingkan dengan pengetahuan baik.

Pengetahuan merupakan hasil mengingat suatu hal, termasuk mengingat kembali kejadian yang pernah dialami baik secara sengaja maupun tidak sengaja dan ini terjadi setelah orang melakukan kontak pengamatan terhadap suatu objek tertentu. Perilaku didasari oleh pengetahuan akan lebih langgeng daripada perilaku yang tidak didasari oleh pengetahuan (misalnya perilaku karena paksaan atau adanya aturan wajib) (Mubarak, 2011).

Pengetahuan pijat bayi adalah hasil tahu dan kesan dalam perawatan kesehatan dan pengobatan dengan menggunakan permainan gerakan pada bayi untuk merangsang pertumbuhan dan perkembangan serta kemampuan pergerakan bayi secara optimal. Pengetahuan yang perlu ibu ketahui mencakup pengertian pijat bayi, kapan waktunya melakukan pijat bayi, siapa saja yang boleh melakukan pijat bayi, apa yang perlu disiapkan ketika akan memijat bayi dan bagaimana teknik pelaksanaan pijat bayi (Roesli, 2008).

Penelitian ini sejalan dengan penelitian yang dilakukan oleh Nunik dwijayanti nugraheni (2013), penelitian berjudul "Hubungan Tingkat Pengetahuan Dan Akses Informasi Tentang Pijat Bayi Dengan Prilaku Pijat Bayi Oleh Ibu Didesa Purwojati Kecamatan Purwojati Kabupaten Banyumas" dalam penelitian ini penulis menggunakan jenis penelitian metode analitik yang bersifat observasional.Dengan menggunakan desain Crossectional.Teknik pengambilan sampling mengunakan purpose sampling melalui pengumpulan data kuesioner.Analisis data yang dugunakan data adalah univariat dan bivariat (Chi Square) nilai $\mathrm{p}=$ o,013 sehingga terdapat hubungan pengetahuan dengan pijat bayi.

Berdasarkan hasil penelitian dapat diasumsikan bahwa pengetahuan merupakan faktor yang mempengaruhi intelektual individu, dimana semakin tinggi atau semakin baik pengetahuan maka akan semakin memahami manfaat pijat bayi, karena pengetahuan merupakan salah satu determinan yang berpengaruh pada pemahaman orang terhadap objek tertentu, responden dengan tingkat pengetahuan baik akan lebih cepat memahami sesuatu, khususnya pijat bayi terkait dengan manfaat pijat bayi, namun terdapat responden yang tidak memahami manfaat pijat bayi, karena pengetahuan kurang yang disebabkan latar belakang responden yang mayoraitas lulusan SMP dan SMA, dengan demikian disarankan kepada ibu untuk meningkatkan pengetahuan tentang pijat bayi dan manfaat pijat bayi dengan cara membaca buku, menonton televise, radio, Koran, majalah, dan bertanya kepada kader ataupun tenaga kesehatan tentang pijat bayi.

Berdasarkan tabel 5 diketahui dari 46 orang, didapatkan distribusi frekuensi responden yang dengan sikap negatif dan tidak pijat bayi sebesar 28 orang $(60,8 \%)$, dan dari 38 orang dengan sikap positif yang tidak pijat bayi sebesar 13 orang $(34,2 \%)$. Hasil uji statistik yang dilakukan dengan menggunakan spss diperoleh p-value $=0,027<\alpha=0,05$. Hal ini menyatakan bahwa Ha diterima, yang artinya terdapat hubungan sikap dengan pelaksanaan pijat bayi, nilai odds ratio 2,991 artinya responden dengan sikap negatif akan memiliki peluang untuk tidak pijat bayi sebesar 2,9 kali dibandingkan dengan sikap negatif.

Pijat bayi merupakan terapi sentuh tertua yang dikenal manusia yang pailing popular.Pijat bayi adalah suatu pengobatan sederhana melalui sentuhan tangan manusia yang dilakukan pada seluruh tubuh bayi. 
Sebenarnya pijat telah dipraktikan diseluruh dunia sejak dahulu kala, termasuk indonesia. Seni pijat diajarkan secara turun temurun walaupun tidak diketahui dengan jelas bagaimana pijat dan sentuhan dapat berpengaruh demikian positif pada tubuh manusia.Kulit merupakan organ tubuh yang berfungsi sebagai reseptor terluas pada manusia.Sensasi sentuh atau raba adalah indera yang aktif berfungsi sejak dini, oleh karena itu, sejak dalam kandungan janin telah dapat merasakan belaian hangat cairan ketuban.Memijat adalah salah satu alternatife yang sudah dibuktikan manfaatnya, tidak hanya orang dewasa bayi juga butuh dipijat meskipun aktivitas yang dilakukan lebih banyak orang dewasa (Puri Mahayu, 2016).

Pijat bayi sebagai bentuk pengobatan alternative menjadi semakin popular karena kesederhanaan, efektifitas biaya, mudah dipelajari dan dapat dilakukan dirumah oleh keluarga, Pijat bayi juga dapat meningkatkan ikatan kasih sayang antara anak dengan orang tua, karena itu pijat bayi sebaiknya dilakukan oleh orang tua bayi (Ria Riksani, 2012).

Sikap (attitude) merupakan reaksi atau respon yang masih tertutup dari seseorang terhadap suatu objek.Manifestasi sikap itu tidak dapat langsung dilihat, tetapi hanya dapat langsung ditafsirkan terlebih dahulu dari perilaku yang tertutup. Sikap belum merupakan suatu tindakan atau aktivitas, akan tetapi merupakan predisposisi tindakan suatu perilaku. Sikap masih merupakan reaksi tertutup, bukan merupakan reaksi terbuka atau tingkah laku terbuka (Notoatmodjo, 2010).Sikap ibu terhadap pelaksanaan pijat bayi adalah sikap yang terbentuk dari interaksi sosial dipengaruhi oleh pengalaman pribadi, kebudayaan, orang yang dianggap penting, media massa, lembaga pendidikan atau agama, emosi seseorang. Kemudian manusia bersikap menerima atau menolak yang terjadi (Azwar, 2011).

Dalam hal ini pemberian sentuhan dalam pemijatan bayi pandangan mata antara orang tua dengan bayi mampu mengalirkan sikap jalinan kasih yang merupakan jalinan komunikasi untuk memupuk cinta kasih secara timbal balik diantara keduanya.Mampu mengurangi kecemasan, meningkatan kemampuan fisik serta meningkatkan percaya diri (Roesli, 2009).

Penelitian ini sejalan dengan penelitian Mulyati (2013), penelitian berjudul "Hubungan Pengetahuan dan Sikap terhadap Perilaku Ibu dalam Pemijatan Bayi di Puskesmas Pamulang Tahun 2011" dalam penelitian ini penulis menggunakan jenis penelitian kuantitatif desain Cross Sectional. Tekhnik pengambilan sampel menggunakan Simple Random Sampling. Analisis data yang digunakan adalah uji validitas dan realibitas (Pearson Product Moment).Sikap positif ibu sebanyak 35 orang (50\%) dan negatif 35 orang (50\%), nilai p o,ooo sehngga terdapat hubungan sikap dengan perilaku ibu melakukan pijat bayi.

Berdasarkan hasil penelitian dapat diasumsikan bahwa sikap merupakan determinan yang mempengaruhi individu untuk melakukan pijat bayi, dimana semakin positif sikap ibu maka akan semakin besar melakukan pijat bayi, sikap ibu yang positif dapat dipengaruhi oleh tenaga kesehatan yang memberikan pendidikan kesehatan tentang pijat bayi, sehingga ibu terbiasa melakukan pijat bayi pada anaknya sesuai dengan kebutuhan bayi, dan bayi pun dapat menikmati manfaat yang diberikan, dengan demikian disarankan kepada ibu untuk melakukan pijat bayi, karena pijat bayi memiliki manfaat baik bagi kesehatan dan tubuh bayi, dan disarankan kepada ibu yang memiliki bayi untuk bertanya pada tenaga kesehatan agar mendapatkan konseling pijat bayi, sehingga ibu melakukan pijat bayi dengan benar dan teratur.

\section{SIMPULAN DAN SARAN}

\section{Simpulan}

Berdasarkan hasil penelitian dan pembahasan maka dapat diambil kesimpulan sebagai berikut:

a. Distribusi Distribusi frekuensi pengetahuan baik $48(57,1 \%)$ orang di Poskesdes Sri Menanti kecamatan Air Hitam, Kabupaten Lampung Barat, Tahun 2017.

b. Distribusi frekuensi sikap negatif $46(54,8 \%)$ orang di Poskesdes Sri Menanti kecamatan Air Hitam, Kabupaten Lampung Barat, Tahun 2017

c. Distribusi frekuensi ibu yang melakukan pijat bayi $43(51,2 \%)$ orang di Poskesdes Sri Menanti kecamatan Air Hitam, Kabupaten Lampung Barat, Tahun 2017

d. Ada hubungan pengetahuan dengan pelaksanaan pijat bayi dengan nilai $\mathrm{p} 0,000$ dan OR 7,286

e. Ada hubungan sikap dengan pelaksanaan pijat bayi dengan nilai $\mathrm{p}$ o,ooo dan OR 2,991 .

\section{Saran}

a. Bagi responden. Penulisan penelitian ini merupakan salah satu bentuk edukasi kepada ibu yang mempunyai bayi tentang pijat bayi dengan harapan ibu dapat menerapkannya pada bayi.

b. Bagi Poskesdes. Sebagai bahan masukan untuk pengambilan keputusan dalam memberikan asuhan kebidanan pada bayi dan untuk peningkatan pelayanan kesehatan ibu dan anak.

c. Bagi STIKes Aisyah. Hasil penelitian ini diharapkan dapat menambah wacana sebagai bahan referensi mengenai hubungan pengetahuan dan sikap ibu dengan pelaksanaan pijat bayi

d. Bagi Peneliti Selanjutnya. Sebagai referensi untuk mengadakan penelitian lebih lanjut tentang pijat bayi dengan variabel yang berbeda dan tempat yang berbeda.

\section{DAFTAR RUJUKAN}

[1] Abdul M, Nasir \& Ideputri, M.E. Metodologi Penelitian Kesehatan, Nuha Medika, Yogyakarta, 2011.

[2] Arikunto, S. Prosedur Penelitian Suatu Pendekatan Praktik. Rineka Cipta, Jakarta, 2010.

[3] Azwar. Sikap Manusia Teori dan Pengukurannya, Pustaka Pelajar, Yogyakarta, 2011.

[4] Badan Pusat Statistik dan Tim. Survei Demografi dan Kesehatan Indonesia, Laporan Pendahuluan Badan Pusat Statistik, Jakarta, 2012.

[5] Baroo'ah, B. Pengaruh Pendidikan Kesehatan tentang Pijat Bayi terhadap Perilaku Ibu dalam Memijat Bayi 
secara Mandiri di Kelurahan Girimargo Sragen, Skripsi, FIKES-UMS, Surakarta, 2015

[6] Departemen Kesehatan RI. Ibu Bayi Sehat, Jakarta, 2002.

[7] Depkes RI. Silabus Untuk Meningkatkan Kinerja Upaya Kesehatan Esensial di Tingkat Kabupaten dan Kota, Jakarta, 2003.

[8] Dewi A., Hubungan antara Pengetahuan dengan Sikap Ibu tentang Pijat Bayi di Kelurahan Wadung Getas Kecamatan Wonosari Klaten, Skripsi, FIKES- UMS, Surakarta, 2012.

[9] Dwijayanti N., Hubungan Pengetahuan Akses Informasi Tentang Pijat Bayi dengan Perilaku Pijat Bayi oleh Ibu di Desa Purwojati Kecamatan Purwojati Kabupaten Banyumas, Skripsi, Cakrawala Galuh Ciamis, 2013.

[10] Kristianingsih A., dkk. Pedoman Penulisan Tugas Akhir Mahasiswa, Laduny, STIKes Aisyah Pringsewu, 2013.

[11] Lapau B. Metodologi Penelitian Kebidanan, Yayasan Pustaka Obor Indonesia, Jakarta, 2015.

[12] Mahayu P. Buku Lengkap Perawatan Bayi dan Balita, Saufa, Yogyakarta, 2015.

[13] Marmi, RK. Asuhan Neonatus, Bayi, Balita dan Anak Prasekolah, Pustaka Belajar, Yogyakarta, 2012.

[14] Mubarak WI. Promosi Kesehatan untuk Kebidanan, Selemba Medika, Jakarta, 2011.

[15] Mulyati, Hubungan Pengetahuan dan Sikap terhadap Perilaku Ibu dalam Pemijatan Bayi di Puskesmas Pamulang Tahun 2011, Skripsi, PSIK- UIN SYARIF HIDAYATULLOH, Jakarta, 2013

[16] Pidarta, M. Landasan Pendidikan: Stimulus Ilmu Pendidikan Bercorak Indonesia , Rineka Cipta, Jakarta, 2014.

[17] Prasetyono, D.S. Teknik-Teknik Tepat Memijat Bayi Sendiri, Diva Press, Yogyakarta, 2009.

[18] Riksani R. Cara Mudah dan Aman Pijat Bayi, Dunia Sehat, Jakarta, 2012.

[19] Roesli, U. Pedoman Pijat Bayi Prematur dan Bayi Usia o3 Bulan. Trubus Agriwidya, Jakarta, 2008.

[20] Sekartini D., \& Barnie EM. Buku Pintar Bayi, Pustaka Bunda, Jakarta, 2011.

[21] Siswosuharjo, S., \& Fitria C. Panduan Super Lengkap Hamil Sehat. Penerbit Plus, Jakarta, 2010.

[22] Subakti Y., \& Deni RA. Keajaiban Pijat Bayi dan Balita, Wahyu Medika, Jakarta, 2008. 